\title{
The Fund's Income Position for FY 2017 - Actual Outcome
}




\section{THE FUND'S INCOME POSITION FOR FY 2017-} ACTUAL OUTCOME

IMF staff regularly produces papers proposing new IMF policies, exploring options for reform, or reviewing existing IMF policies and operations. The following document has been released and is included in this package:

- The Staff Report prepared by IMF staff and completed on August 15, 2017 for the information of the Executive Board. The paper was prepared following completion of the IMF's FY 2017 external audit.

The IMF's transparency policy allows for the deletion of market-sensitive information and premature disclosure of the authorities' policy intentions in published staff reports and other documents.

Electronic copies of IMF Policy Papers are available to the public from http://www.imf.org/external/pp/ppindex.aspx

\section{International Monetary Fund Washington, D.C.}




\section{INTERNATIONAL MONETARY FUND}

August 15, 2017

\section{THE FUND'S INCOME POSITION FOR FY 2017-ACTUAL} OUTCOME

\section{EXECUTIVE SUMMARY}

This paper reports the Fund's income position for FY 2017 following the closing of the Fund's accounts for the financial year and completion of the external audit. Total FY 2017 net income, including income from surcharges, amounted to SDR 1.9 billion or about SDR 258 million higher than estimated in April, reflecting mainly a larger than anticipated gain reported under IAS 19 (the accounting standard for employee benefits).

GRA net income for FY 2017 was about SDR 1.49 billion and has been placed to the Fund's reserves. In accordance with decisions taken in April 2017, a net transfer of currencies amounting to SDR 1.41 billion was made in August 2017 from the GRA to the Investment Account. The placement of the net income to the Fund's reserves has further strengthened the Fund's precautionary balances, which reached SDR 16.7 billion at the end of FY 2017. 
Approved By

Andrew Tweedie (FIN)
Prepared by the Finance Department (Maria Manno, Amadou Ndiaye, Diviesh Nana, and Yan Sun-Wang under the guidance of David Andrews), in consultation with the Legal Department and the Office of Budget and Planning.

1. This paper presents the Fund's net income for FY 2017. The actual outcome reported in this paper follows the closing of the Fund's accounts for the financial year and completion of the FY 2017 external audit conducted by PricewaterhouseCoopers, the Fund's external auditor. ${ }^{1}$

\section{The overall FY 2017 net income was about SDR 1.9 billion, or SDR 258 million higher} than the April projections (Table 1). ${ }^{2}$ The outcome mainly reflects a larger than anticipated gain reported under IAS 19 (SDR 273 million). Changes in lending income and expenses did not have a major impact. The results are discussed below:

- IAS 19 timing adjustment. The FY 2017 IAS 19 timing adjustment amounted to SDR 720 million compared to the April estimate of SDR 447 million (Table 2). ${ }^{3}$

The timing adjustment comprises the sum of two factors:

(i) The difference between the actuarially determined annual IAS 19 expense that measures, on an accrual basis, the increase in obligations under the staff retirement plan stemming from an additional year of staff service and the funding (cash appropriation) for the year. The IAS 19 expense for FY 2017 amounted to SDR 381 million compared to the actual funding of SDR 134 million giving rise to a timing difference (loss) of SDR 247 million. The difference was higher than the April estimate and reflects mainly the higher IAS 19 expense following the recognition of past service costs related to two plan amendments approved during the year: (a) expanded coverage under the Fund's medical benefits plan, and (b) updated factors for participants who choose to commute a portion of their pension.

(ii) Actuarial gains and losses that arise from revaluing retirement plan obligations and plan assets as required by IAS 19. Under IAS 19, these actuarial gains and losses are fully reflected in the Fund's income in the year that they arise. The increase in the FY 2017 actuarial gains from the April projection of SDR 605 million to SDR 967 million can be attributed largely to (a) higher returns earned from plan assets than earlier estimated reflecting the stronger than expected performance of the portfolio in the final quarter of

\footnotetext{
${ }^{1}$ See Audited Financial Statements for the Financial Year Ended April 30, 2017.

${ }^{2}$ See Review of the Fund's Income Position for FY 2017 and FY 2018.

3 The Fund's pension and employee benefit expense is determined by the provisions of IAS 19, under International Financial Reporting Standards (IFRS). See IAS 19 Accounting for Employee Benefits in the Review of the Fund's Income Position for FY 2017 and FY 2018 for further background.
} 
FY 2017; and (b) the actual liability experience during FY 2017 differing from the actuarial assumptions underlying the previous year valuation.

- Income of the Investment Account. Investment income from the Fixed-Income Subaccount amounted to SDR 80 million, slightly higher than the earlier estimate of SDR 75 million. The Endowment Subaccount returned SDR 447 million, modestly lower than the SDR 461 million projected in April. ${ }^{4}$

- Lending income. Lending income (including surcharges) amounted to SDR 1.43 billion, in line with the April estimate. Service charges, which comprise only about 2 percent of lending income, were lower following delays in six projected purchases, while income from the margin, commitment fees, and surcharge income was broadly in line with previous projections.

- Expenses. Total expenses of SDR 827 million were about SDR 3 million lower than projected in April. Capital budget items expensed were lower by about SDR 10 million mainly due to a delay in the start-up of a major campus improvement initiative, as well as lower than expected HQ1 renewal expenses. Depreciation was marginally lower than earlier projections, while net administrative expenditures ended the year slightly above the earlier estimate, reflecting higher-than-projected spending spread across several areas (building facilities, IT, and other services, as well as an additional contribution of US\$2 million to the Retired Staff Benefits Investment Account). ${ }^{5}$ Table 3 provides a reconciliation between the net administrative budget outturn and the administrative expenses in the FY 2017 audited financial statements. ${ }^{6}$

3. Precautionary balances. Precautionary balances amounted to SDR 16.7 billion at year end, higher than the earlier projection of SDR 16.4 billion. The increase is mainly attributable to the overall IAS 19 timing adjustment being higher than estimated.

\footnotetext{
${ }^{4}$ The endowment assets are invested in a conservative, globally diversified portfolio consisting of fixed income assets and a limited portion of equities (including real estate investment trusts) in accordance with a strategic asset allocation benchmark. Following the recent completion of the three-year phasing-in of the passively managed portion in December 2016 and partial funding of the actively managed portion during the year, the endowment is now 98 percent invested, with the remaining gold sales profits temporarily held in USD denominated short-term fixed deposits.

5 See FY2017-Output Cost Estimates and Budget Outturn Paper.

${ }^{6}$ The administrative expenses reported in the audited financial statements include non-operational costs, i.e., the IAS 19 timing adjustment.
} 
Table 1. Income and Expenditures for FY 2017

(in millions of SDRs)

\begin{tabular}{|c|c|c|c|}
\hline & $\begin{array}{l}\text { April } \\
\text { Projections 1/ } \\
\text { (a) }\end{array}$ & $\begin{array}{l}\text { Actual } \\
\text { Outcome } \\
\text { (b) }\end{array}$ & $\begin{array}{l}\text { Difference } \\
(c=b-a)\end{array}$ \\
\hline A. Operational income & 1,017 & 1,014 & -3 \\
\hline Lending income & 855 & 849 & -6 \\
\hline Margin for the rate of charge & 487 & 486 & -1 \\
\hline Service charges & 35 & 30 & -5 \\
\hline Commitment fees & 333 & 333 & 0 \\
\hline Fixed-Income Subaccount & 75 & 80 & 5 \\
\hline Interest free resources 2/ & 11 & 9 & -2 \\
\hline Reimbursements & 76 & 76 & 0 \\
\hline CCR Trust and SDR Department & 6 & 6 & 0 \\
\hline PRG Trust & 70 & 70 & 0 \\
\hline B. Expenses 3/ & 830 & 827 & -3 \\
\hline Net administrative expenditures & 768 & 777 & 9 \\
\hline Capital budget items expensed & 32 & 22 & -10 \\
\hline Depreciation & 30 & 28 & -2 \\
\hline C. Net operational income (A-B) & 187 & 187 & $\mathbf{0}$ \\
\hline Surcharges & 584 & 583 & -1 \\
\hline IAS 19 timing adjustment 4/ & 447 & 720 & 273 \\
\hline Endowment Subaccount (gold profits) investment income & 461 & 447 & -14 \\
\hline Net income position 5/ & 1,679 & 1,937 & 258 \\
\hline \multicolumn{4}{|l|}{ Memorandum Items: } \\
\hline Outstanding Fund credit (average balances, SDR billions) & 48.7 & 48.6 & \\
\hline SDR interest rate (average, in percent) & 0.2 & 0.2 & \\
\hline US\$/SDR exchange rate (average) & 1.38 & 1.38 & \\
\hline Precautionary balances (end of period, SDR billions) & 16.4 & 16.7 & \\
\hline \multicolumn{4}{|l|}{ Source: Finance Department and Office of Budget and Planning } \\
\hline \multicolumn{4}{|l|}{ 1/ See Review of the Fund's Income Position for FY 2017 and FY 2018.} \\
\hline \multicolumn{4}{|c|}{$\begin{array}{l}\text { 2/ Interest free resources reduce the Fund's costs and therefore provide implicit returns. Since the Fund invests its reserves in the } \\
\text { IA to earn a higher return, the interest free resources retained in the GRA are mainly attributable to the SCA-1, unremunerated } \\
\text { reserve tranche positions not represented by gold holdings, and GRA income for the year not yet transferred to the IA. These } \\
\text { resources reduce members' reserve tranche positions and the Fund's remuneration expense resulting in implicit income for the } \\
\text { Fund. }\end{array}$} \\
\hline \multicolumn{4}{|c|}{$\begin{array}{l}\text { 3/ See Table } 2 \text { for a reconciliation to the administrative expenses reported in the Audited Financial Statements for the Financial } \\
\text { Year Ended April 30, } 2017 \text {. }\end{array}$} \\
\hline \multicolumn{4}{|c|}{$\begin{array}{l}\text { 4/ IAS } 19 \text { is the accounting standard that prescribes the accounting treatment of pensions and employee benefit expenses, and } \\
\text { involves actuarial valuations (see Table 3). }\end{array}$} \\
\hline 5/ See "Total comprehensive income" of the Audited Financial Statement & $s$ for the Financial $Y e$ & r Ended April & 2017. \\
\hline
\end{tabular}


4. No decisions are required at this time. The Executive Board took all necessary decisions in April 2017 during the review of the Fund's income position for FY 2017 and FY 2018. Income from the Endowment Subaccount of SDR 447 million is retained in the Investment Account (IA), while income from the Fixed-Income Subaccount of SDR 80 million has been transfered to the GRA and used for meeting the administrative expenses of the Fund. FY 2017 GRA net income (SDR 1.49 billion) has been placed in equal parts to the Fund's general reserve and special reserve. ${ }^{7,8}$ Currencies amounting to SDR 1.41 billion were transferred from the GRA to the IA in August $2017 .^{9}$

Table 2. Reconciliation of IAS 19 Adjustments-FY 2017

(in millions of SDRs)

\begin{tabular}{lcc}
\hline & \multicolumn{2}{c}{ FY 2017 } \\
\cline { 2 - 3 } & $\begin{array}{c}\text { April } \\
\text { Projections 1/ }\end{array}$ & $\begin{array}{c}\text { Actual } \\
\text { Outcome }\end{array}$ \\
\hline Accrual vs. Funding & $-\mathbf{1 5 8}$ & $\mathbf{- 2 4 7}$ \\
Pension cost accrual & -292 & -381 \\
Pension funding & 134 & 134 \\
Actuarial gains & $\mathbf{6 0 5}$ & $\mathbf{9 6 7}$ \\
Total IAS 19 timing difference & $\mathbf{4 4 7}$ & $\mathbf{7 2 0}$ \\
\hline Source: Finance Department & & \\
1/ See Review of the Fund's Income Position for FY 2017 and FY 2018. & & \\
\hline
\end{tabular}

\footnotetext{
${ }^{7}$ GRA net income (including SDR 80 million transferred from the Fixed-Income Subaccount) is SDR 1,490 million. This comprises total net income of SDR 1,937 million less the gain from the endowment of SDR 447 million, which was retained in the IA (see Table 1).

${ }^{8}$ See page 6 of Audited Financial Statements for the Financial Year Ended April 30, 2017.

${ }^{9}$ Decision No. 6 in Review of the Fund's Income Position for FY 2017 and FY 2018 provides for the transfer of currencies equivalent to the GRA net income of FY 2017 (SDR 1,490 million) to the IA; and Decision No. 4 in Review of the Fund's Income Position for FY 2017 and FY 2018 provides for the transfer to the GRA of the income of the Fixed Income Subaccount of the IA (SDR 80 million) for meeting FY 2017 administrative expenses. Consistent with past practice, and for operational expediency, the two transfers are netted, resulting in a net transfer of SDR 1.41 billion which took place in August 2017.
} 
Table 3. Reconciliation of Administrative Expenses-FY 2017

(in millions of U.S. dollars, unless otherwise stated)

Net administrative budget outturn 1/

1,066

IAS 19 (accrual vs. funding) timing adjustment 2/

$\begin{array}{ll}\text { Depreciation } & 39\end{array}$

$\begin{array}{ll}\text { Capital budget items expensed } & 30\end{array}$

Reimbursements from PRG Trust, CCR Trust, and SDR Department $\quad-105$

$\begin{array}{ll}\text { Total administrative expenses per the audited financial statements (USD millions) } & 1,385\end{array}$

$\begin{array}{lll}\text { Total administrative expenses per the audited financial statements (SDR millions) } & 3 / \quad 1,001\end{array}$

Source: Finance Department and Office of Budget and Planning

Totals may not add due to rounding differences.

1/ See FY2017-Output Cost Estimates and Budget Outturn Paper.

2/ Reflects the difference between the IAS 19 expense (USD 540 million) and the actual funding in FY 2017 (USD 185 million).

3/ Based on the effective weighted average FY 2017 U.S. dollar/SDR exchange rate of 1.38 for all expenses; the effective average exchange rate for individual expenditure components may differ due to the timing of exchange rate movements during the year. 